\title{
The Capital Structure Puzzle Revisited
}

\author{
James L. Berens \\ Charles J. Cuny \\ University of California, Irvine
}

Corporate finance researchers have long been puzzled by low corporate debt ratiosgiven debt's corporate tax advantage. This article recognizes that firm value typically reflects a growing stream of earnings, while current debt reflects a nongrowing stream of interestpayments. Debt to value is therefore a distorted measure of corporate tax shielding. Even with very small debt-related costs, this may explain the observed magnitude and cross-sectional variation of debt ratios. Since this variation may be independent of tax shielding, debt ratios provide an inappropriate framework for empirically examining the trade-off theory of capital structure.

The trade-off theory of capital structure argues that value-maximizing firms attain an optimal capital structure by balancing the corporate tax benefits of debt against the (personal tax, bankruptcy, or agency) costs associated with debt. Though widely utilized in corporate finance, the trade-off theory has been criticized on the basis that it is not adequately descriptive of observed capital structures Myers (198411. Even casual empiricism suggests that the trade-off theory is somewhat lacking: How can debt's marginal disadvantage be as great as its margina advantage when a typical firm has a debt ratio in the 25 to 30 percent range?

We thank RUT\&nor, Roben Haugen, Neal Stoughton, Philippe John, Oded Sarig, two anonymous referees, Franklin Allen (the editor), and seminar particpants at University of California Irvine, University of California Riverside, and Wharton. An earlier version entitled "Growth and Leverage" was presented at the 1994 Western Finance Association meetings. Address conespondence to Charles J. Cuny, Graduate School of Mangement. University of California, Irvine, CA 92717. 
This article shows that, once nominal growth is recognized in firm valuation, the debt ratio becomes a badly distorted measure of tax shielding. When firms issue debt with fixed interest payments, growing cash flows generated by the firm are not matched by the interest payments on current debt. Additional debt required for future tax shielding purposes will be issued over time. These future debt issues are not reflected in the current amount of debt. The fact that future growth in the firms cash flows is reflected in the equity value but not the debt value implies a significant impact on firms' debt ratios. The impact of nominal growth on debt ratios, however, is largely independent of the extent to which interest is used to shield income from taxes.

This observation implies that much of the research regarding corporate capital structures has been misguided. The preponderance of capital structure research has relied on the debt to value, or debt, ratio (usually defined as the market value of debt divided by the market value of debt plus equity) as a measure of the degree of tax shielding via interest. We show that, for reasonable levels of growth, firms may exhibit relatively low debt ratios with considerable cross-sectional variation, even while fully shielded from taxes. Empirical tests of capital structure, because they have almost exclusively used debt ratios, have generally not tested the extent to which debt is used to shield income from corporate taxes. In short, tests which use the debt ratio as their leverage measure have not accurately tested the tradeoff theory of capital structure.

This article generalizes and discusses empirical implications for these observations about capital structure. Section 1 reviews the current state of knowledge in the area. Section 2 analyzes the case of a riskless growing firm. Section 3 generalizes to the case of a risky firm. Personal taxes and depreciation are included; the model is then extended to allow for the carrying of tax losses. Implications for studying capital structure are discussed in Section 4, while Section 5 concludes.

\section{The State of the Art}

\subsection{Capital structure in a static setting}

In their second seminal paper on corporate capital structure, Modigliani and Miller (1963) show that firm value is an increasing function of leverage due to the tax deductibility of interest payments at the corporate level. However, the implication of the Modigliani-Miller model with corporate taxes seems embarrassingly extreme: valuemaximizing firms should finance with 100 percent debt. The "comer solution" implied by their model is very much at odds with empirical observations of firm behavior. 
In the 30 years since, enormous academic effort has gone into identifying the relevant costs associated with debt financing that firms presumably trade off against this substantial corporate tax benefit. Although direct bankruptcy costs are probably small, other potentially important factors include personal taxes, agency costs, asymmetric information, product/input market interactions, and corporate control considerations. Surveys of this literature include Bradley, Jarrell, and Kim (1984), Harris and Raviv (1991), Masulis (1988), and Miller (1988).

The trade-off theory of capital structure argues that firms balance the corporate tax benefit of debt against these various costs. The theory yields an intuitively pleasing interior optimum for firms, and gives a rationale for cross-sectional variation incorporate debt ratios: firms with different types of assets will have different bankruptcy and agency costs and different optimal debt ratios. Additionally, firms with different amounts of alternative tax shields will have different marginal tax benefits of debt, thus implying different levels of optimal debt ratios. While there is less than total agreement on the exact costs and benefits of leverage, and what role they explicitly play in firms' capital structure decisions, most financial economists accept some version of the trade-off theory.

Early empirical evidence on the trade-off theory [e.g., Bradley, Jarrell, and Kim (1984)] yielded mixed results. However, recent studies examining capital structure responses to changes in corporate tax exposure [Givoly, Hayn, Ofer, and Sarig (1992), MacKie-Mason (1990), and Trezevant(1992)] provide evidence supporting the trade-off theory.

An apparently serious problem with the trade-off theory is that the debt ratios seemingly predicted by theory are significantly higher than those observed. Average debt ratios of US. corporations have typically been around 25 to 30 percent. Thus, observed debt ratios seem much too low relative to what the trade-off theory predicts, based on the relative magnitudes of debt's benefits and costs, which Miller (1977) terms "horse and rabbit stew." Myers (1984) argues that the trade-off theory also fails to predict the wide degree of cross-sectional and time variation of observed debt ratios.

\subsection{Capital structure in a dynamic setting}

Additional insights about capital structure can be obtained by moving to a dynamic, multiperiod setting. Modigliani (1982) extends Farrar and Selwyn (1967) to show that the marginal value of leverage may depend on inflation, as well as the personal tax rates on debt and equity, and the corporate tax rate. Although he finds the marginal value of leverage may be quite sensitive to inflation, he concludes that it remains moderate in practice. 
Barnea, Haugen, and Talmor (1987) develop a multiperiod capital structure model that includes differential costs of debt and equity financing as well as the possibility of real firm growth. In an important insight, they recognize that a firm's optimal multiperiod debt policy sets interest relative to taxable income on a period-by-period basis. In their model, a growing, riskless firm can shield all of its income from corporate taxation and achieve an interior optimal capital structure.

Lewis (1990) argues that, due to debt maturity considerations, there may be more than one current debt ratio corresponding to a set of future interest payments. For a given set of interest payments over time, a firm's current debt ratio can vary with its debt maturity structure, reflecting the term structure of interest rates as well as different default risks. In this context, there may be multiple optimal debt ratios even if the set of interest payments is unique.

Fischer, Heinkel, and Zechner (1989) consider the optimal dynamic corporate recapitalization policy in the presence of recapitalization costs. They find that a firm's debt ratio may optimally vary over time, suggesting an optimal range rather than level for the debt ratio.

This article shows that a riskless firm's optimal debt ratio can be signficantly less than 100 percent even in the Modigliani and Miller (1963) model with no offsetting disadvantage of debt. Risky firms may also have debt ratios significantly less than 100 percent with only small debt-related costs, such as bankruptcy or agency costs, or personal taxes. These are manifestations of a more basic principle: in the presence of nominal growth (either real growth or simply inflation), the debt ratio becomes a distorted measure of corporate tax shielding, since firm value reflects growth while current debt does not. We emphasize that this distortion occurs for any debt ratio, whether optimal or not. Thus, firms may shield a large fraction of their earnings from corporate tax and still exhibit a relatively low debt ratio. Growth, and changing prospects for growth, may drive the magnitude of debt ratios, as well as both their cross-sectional and time variation. From the viewpoint of the trade-off theory, since debt ratios provide an inaccurate measure of corporate tax shielding, they are unlikely to be an appropriate measure of the benefit/cost tradeoff.

\section{A Simple Example}

Consider a firm whose annual earnings (before interest and taxes) are a riskless growing perpetuity starting at $C$ dollars and growing at rate $g$. Let $r_{f}$ be the nominal risk-free rate. With no corporate tax, the present value of the firm is

$$
\bar{v}=\frac{C}{r_{f}-g} .
$$


Suppose the firm supports a growing perpetuity of annual interest payments, starting at $I$ and growing at $g$, thus providing a shield from corporate tax. With a corporate tax rate $\boldsymbol{\tau}_{c}$, the value of the levered firm is

$$
V_{L}=\frac{\left(1-\tau_{c}\right) C+\tau_{c} I}{r_{f}-g}=V_{U}+\frac{\tau_{c} I}{r_{f}-g}
$$

for $I \leq C$, where $V_{U}=\left(1-\tau_{c}\right) C /\left(r_{f}-g\right)$ is its unleveled value. Suppose that the firm issues level perpetual debt. ${ }^{1}$ Let $D$ be the value of the firm's current debt outstanding. Since $I$ is next year's interest payment, $I=r_{f} D$, and the debt ratio is

$$
\frac{D}{V_{L}}=\frac{r_{f}-g}{r_{f}} \cdot \frac{I}{\left(1-\tau_{c}\right) C+\tau_{c} I}
$$

for $I \leq C$. The first term reflects growth, while the second reflects tax shielding (interest to after-tax cash flow): the debt ratio, as a measure of tax shielding, is distorted by growth. The levered firm value can also be written

$$
V_{L}=V_{U}+\frac{r_{f}}{r_{f}-g} \tau_{c} D
$$

for $r_{f} D=I \leq C$. The marginal tax benefit of debt $\boldsymbol{r}_{f} \boldsymbol{\tau}_{\boldsymbol{c}} /\left(\boldsymbol{r}_{\boldsymbol{f}}-\boldsymbol{g}\right)$ : need no longer equal the corporate tax rate $\boldsymbol{\tau}_{c}$, similar to Modigliani (1982).

The relation between the value of the levered firm and its debt is graphed (in bold) in Figure 1. Note that debt is bounded above by firm value: $D \leq V_{L}$. For $g=0$, we have the familiar Modigliani-Miller case: the optimal capital structure has a debt ratio of 100 percent, and the firm is fully tax shielded.

However, for $g>0$, the firm achieves full tax shielding at the kink $(I=C)$, even though the debt ratio at this point is less than 100 percent. Although the firm could issue debt beyond this point ( $I>C$, the dotted line), it gains no tax benefit in so doing. Assuming any small amount of bankruptcy costs when interest is greater than earnings $(I>C)$, the optimal capital structure is achieved at the kink $\left(I^{*}=C\right)$ The optimal debt ratio is less than 100 percent, although the firm is fully tax shielded. (For $g<0$, the $D \leq V_{L}$ constraint is binding: the firm cannot achieve full tax shielding since $I=C$ is not feasible.) In a model with differential costs of debt and equity financing, Barnea, Haugen, and Talmor (1987) similarly find an interior optimal capital structure with positive growth, and all-debt financing with nonpositive growth.

\footnotetext{
${ }^{1}$ More generally, this may be any combination of debt securities characterized by periodic fixed interest payments on outstanding principal. Examples include single-period debt, regular corporate bonds, or (level) perpetual debt.
} 


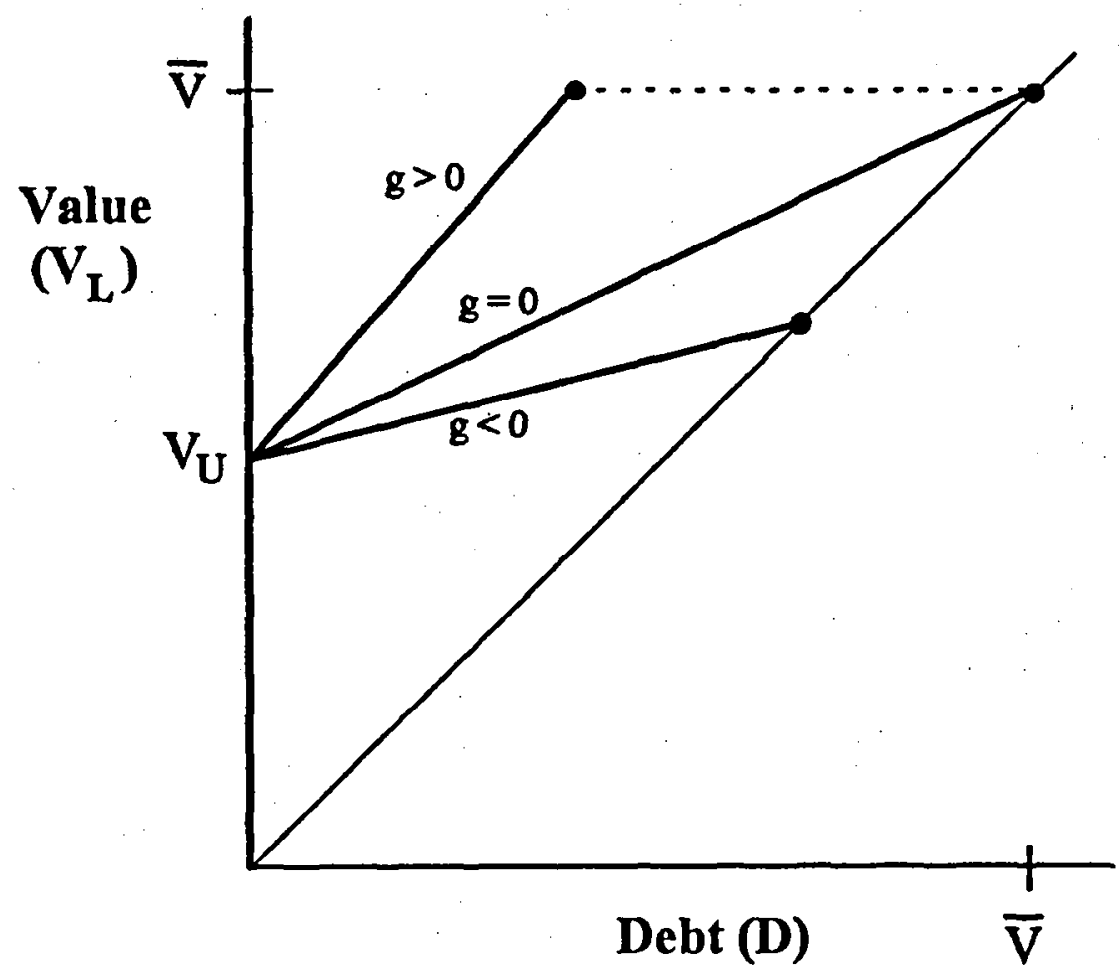

\section{Figure 1}

Levered value of riskless firm

The 45-degree Line represents a debt ratio of 100 percent. For zero growth, full tax shielding is achieved with a debt ratio of 100 percent. For positive growth, full tax shielding is achieved with a debt ratio less than 100 percent. For negative growth, full tax shielding is unachievable, even with a debt ratio of 100 percent

For $g>0$, the optimal capital structure is $I^{*}=\mathrm{C}$ : the firm protects all of its earnings from corporate tax. The optimal debt level is $D^{*}=\frac{C}{r_{f}}$; the firm is fully tax shielded, $C_{Z}^{*}=\bar{V}=\frac{C}{r_{y}-\mathbf{g}}$; the optimal debt ratio is

$$
\left(\frac{D}{V_{L}}\right)=\frac{r_{f}-g}{r_{f}} .
$$

(For $g \leq 0$, the optimal debt ratio is 100 percent.)

Although the firm is fully tax shielded, and all earnings are allocated to interest payments on debt, the optimal debt ratio is less than 100 percent when $\mathrm{g}>0$. How can the equity ratio be positive? What claim can equityholders have on the firm? Notice that earnings allocated to interest grow over time. In year 1, this is C dollars, just 
enough to support flat perpetual debt $D$. In year 2 , this is $(1+g) C$ dollars, more than enough to support $D$. Therefore, in year 1 (and in subsequent years) the firm can issue additional debt. Funds thus raised belong to equityholders. With fixed interest payment debt, even if all current earnings accrue to debt holders growth accrues to equityholders.

This argument essentially relies on the observation that firms issue debt with fixed interest payments. However, firms are generally growing, both from inflation and in real terms. A growing firm must issue additional debt over time to generate growing interest payments (and keep its debt ratio constant). Current interest payments reflect current earnings; current debt reflects a flat stream of interest payments (and thus a flatearnings stream), while firm value reflects a growing earnings stream. Growth thus distorts the debt ratio as a measure of tax shielding: a growing firm, even fully shielded from taxes at all times, may exhibit a debt ratio of less than 100 percent. Furthermore, this distortion may be significant, as shown by the following two examples.

Example 1. First, consider just the effect of injection; assume zero real growth. With an annual risk-free rate of 5.2 percent and an inflation rate of 3.1 percent, based on historical estimates of long-term government bond yields and inflation from Ibbotson Associates (1994) for the period 1926 to 1993, the risk-less firm's debt ratio is 40 percent.

This number stands in stark contrast to the Modigliani-Miller model's prediction of a 100 percent debt ratio. Alternative more recent historical estimates of $r_{f}=9.2$ percent and inflation of 5.9 percent for 1974 to 1993 give a debt ratio of 36 percent. Inflation alone may thus have a substantial effect on the level of the debt ratio.

Example 2. Now consider the effect different real growth rates across firms may have on their debt ratios. With 1974 to 1993 estimates for $r_{f}$ and inflation, a riskless firm with +2.0 percent real growth has a 13 percent debt ratio; 0 percent real growth implies a 36 percent debt ratio; -2.0 percent real growth implies a 59 percent debt ratio. Growth firms have relatively low optimal debt ratios: growth affects firm value, but not current debt value. Different real growth rates may thus have a substantial effect on the variation of debt ratios across firms, even holding tax shielding constant.

These examples illustrate three important implications of nominal growth.. First, with positive nominal growth and small debt-related costs, firms can have, optimal debt ratios well below 100 percent, even with full tax shielding. This effect is substantial: predicted debt ratios are in line with observed debt ratios. Second, firms with high 
real growth will normally have debt ratios lower than those of firms with low or negative real growth. ${ }^{2}$ This can account for the substantial variation in debt ratios observed across firms. Third, debt ratios provide a badly distorted measure of tax shielding. Thus, if we want to know whether a firm is using debt to shield itself from corporate taxation, it is inappropriate to examine its debt ratio.

None of these implications depend on growth being permanent. For a fully shielded firm, the effects of inflationary and real growth in earnings are easily separated. At time $t$, the debt satisfies $r_{f} D_{t}=$ $(1+i) C_{b}$, while the firm value can be written

$$
V_{t}=\frac{C_{t}}{R_{f}}+P V G O_{t},
$$

where $R_{f}$ is the real interest rate, $i$ is the inflation rate, and $P V G O$ is the present value of real growth opportunities. Using the Fisher equation, the fully shielded firm's debt ratio can be written

$$
\left(\frac{D}{V}\right)_{t}=\left[\left(R_{f}+\frac{i}{1+i}\right)\left(\frac{1}{R_{f}}+\frac{P V G O_{t}}{C_{t}}\right)\right]^{-1}
$$

For a given real interest rate, both higher inflation and increased real growth opportunities act to decrease the firm's debt ratio.

\section{Personal Taxes, Depreciation, and Uncertainty}

The previous section provided a simple example with no personal taxes, depreciation, uncertainty, or financial distress costs. This section includes the first three of these elements; as in DeAngelo and Masulis (1980), personal taxes provide debt-related costs. In this context, the firm need no longer shield all its earnings from corporate taxes due to the personal tax costs of debt. Although the firm may now pay corporate tax, the debt ratio remains a badly distorted measure of tax shielding, while additional distortionary effects may also occur.

The capital budgeting and taxation literature has already recognixed two effects on firm valuation arising from the presence of an asset-neutral, fully anticipated inflation. First, the presence of inflation raises the effective real tax rate on capital gains because capital gains are not indexed to inflation [see Hong (1977), Nelson (1976), and Schall (1984)]. For example, a purely inflationary increase in stock prices hurts investors by subjecting them to capital gains taxation even though they have received no increase in real stock prices. Second,

2 Note that this effect is independent of the Myers (1977) agency effect of debt. Certainly, crosssectional differences in financial distress costs related to real growth will compound the effect. 
inflation affects the real value of depreciation charges because depreciation is based on "historic" costs rather than current value [see Feldstein (1980), Thus, as prices rise, the real value of depreciation falls. Both of these effects decrease firm value.

We further note that both effects also affect the magnitude of the tax advantage of debt in the presence of inflation. In particular, these effects generate additional distortions in the debt ratio as a measure of tax shielding. In order to examine these effects, we extend the simple model to a firm with a growing nominal perpetuity of risky earnings, and include personal taxes. Section 3.1 considers the case where corporate tax loss carryforwards and carrybacks are not allowed, while Section 3.2 allows unlimited tax loss carrying. The model with no tax loss carrying is similar to that of DeAngelo and Masulis (1980) and the multiperiod extensions of Barnea, Haugen, and Talmor (1987) and Lewis (1990). The model with tax loss carrying is similar to that of Mayer (1986), which has a multiperiod framework without real growth or inflation and allows only tax loss carryforwards.

\subsection{No loss carry forwards or carrybacks}

Consider a firm whose annual expected earnings (before interest, depreciation, and taxes) are a growing nominal perpetuity $\left\{C_{t}\right\}$, growing at rate g. Actual, uncertain earnings are given by $\left\{X_{t}\right\}$; these are independent, nonnegative, and after detrending for growth, identically distributed. Let $F$ be the cumulative distribution function for normalized earnings $\tilde{X}_{t} / C_{t}$; its density is $f$, and $\bar{F}(\cdot)=\mathbf{1}-\boldsymbol{F}(\cdot)$. The firm's capital structure policy is determined by its interest payments $\left\{I_{t}\right\}$.

Capital investment expenditures (depreciable costs) for period t are given by $A_{t}=a C_{t}$ while depreciation charges are given by $B_{t}=b C_{b}$, both proportional to expected earnings. These are taken to be exogenous, reflecting the firm's investment policy. Note that depreciable costs are a cash flow not included in earnings, and generate future depreciation charges. Since $a$ reflects investment policy, it depends on the real growth level, while $b$ depends on both the real growth and inflation levels. ${ }^{3}$

All after-tax corporate profits are paid out to equityholders, either in the form of dividends or share repurchases. Interest is not subject to corporate tax, equity earnings are subject to corporate tax $\boldsymbol{\tau}_{\boldsymbol{c}}$. Interest is subject to personal tax at the ordinary income rate $\boldsymbol{\tau}_{\boldsymbol{d}}$; equity earnings are subject to a lower personal tax rate $\boldsymbol{\tau}_{\boldsymbol{e}}$ (reflecting a combination of dividends, taxed at $\boldsymbol{\tau}_{\boldsymbol{d}}$ and share repurchases, taxed at the effective

\footnotetext{
${ }^{3}$ since current allowed depreciation is generated by past capital investments, $\mathrm{b}$ and a are related. The exact relation depends on the tax status of the capital Investments. For example, if the apitd investments are depreciated straight-line over $n$ years, then $\mathrm{b}=(\mathrm{a} / \mathrm{ng})\left[1-(1+\mathrm{g})^{-\mathrm{n}}\right]$.
} 
capital gains rate $\boldsymbol{\tau}_{\boldsymbol{g}}$ ). All investors are risk neutral; the tax-free nominal interest rate is $r$. We assume $\left(1-\tau_{d}\right)>\left(1-\tau_{e}\right)\left(1-\tau_{c}\right)$, or equivalently, $\left(\tau_{d}-\tau_{e}\right) /\left(\mathbf{1}-\tau_{e}\right) \tau_{c}<1$ : when earnings are certain, debt has the overall tax advantage.

At each period $t$, the firm's next-period interest payment $I_{t+1}$ is chosen to maximize firm value. Any unused tax shields are lost: no loss carryforwards or carrybacks are allowed (an assumption relaxed in the next section). By use of debt financing, a firm can lower its corporate tax bill in any period to zero, but no lower. The firm faces the following capital structure policy consideration: an optimal level of debt trades off certain higher personal tax payments for possible corporate tax savings (if earnings are sufficiently high). An optimal solution with positive corporate tax payments may therefore exist even with a personal tax rate below the corporate tax rate, and no depreciation.

If the firm's earnings fall below its promised interest payments for a period, it is assumed the firm can raise funds against future cash flows.' Thus, the firm never incurs bankruptcy as long as the promised interest payment is less than the equity claim on future cash flows.

After current interest and earnings are paid for a period, the firm value equals the present value of next period's: appreciated firm value (after personal tax at rate $\boldsymbol{\tau}_{\boldsymbol{g}}$ ) plus interest to be paid (after personal tax at rate $\boldsymbol{\tau}_{\boldsymbol{d}}$ ) plus expected equity earnings (after corporate tax at rate $\boldsymbol{\tau}_{\boldsymbol{c}}$ and personal tax at rate $\boldsymbol{\tau}_{\boldsymbol{e}}$ ). Thus, the dynamic optimization problem faced by the firm in period $t$ is

$$
\begin{aligned}
V_{t}= & \max _{t_{t+1}} \frac{1}{1+r}\left(\left[V_{t+1}-\tau_{g}\left(V_{t+1}-V_{t}\right)\right]+\left(1-\tau_{d}\right) I_{t+1}+\left(1-\tau_{e}\right)\right. \\
& \left.\times E_{t}\left[\tilde{X}_{t+1}-I_{t+1}-A_{t+1}-\tau_{c} \cdot \max \left(0, \tilde{X}_{t+1}-I_{t+1}-B_{t+1}\right)\right]\right),
\end{aligned}
$$

where $V_{t}$ denotes period $t$ firm value, and $E_{t}$ denotes the expectation with respect to $\tilde{\boldsymbol{X}}_{\boldsymbol{t}+\mathbf{1}}$. Note that capital investment $\mathrm{A}$ affects equity earnings while depreciation $B$ affects taxable corporate income. Since the firm value grows at rate $g$, the optimization can be rewritten as

$$
\begin{aligned}
V_{t}= & \max _{I_{t+1}} \frac{1}{1+r}\left[\left(1+g-\tau_{g} g\right) V_{t}+\left(1-\tau_{e}\right)(1-a) C_{t+1}\right. \\
& -\left(\tau_{d}-\tau_{e}\right) I_{t+1}-\left(1-\tau_{e}\right) \tau_{c} \\
& \left.\times \int_{\left(I_{t+1}+B_{t+1}\right) / C_{t+1}}^{\infty}\left(x C_{t+1}-I_{t+1}-B_{t+1}\right) d F(x)\right]
\end{aligned}
$$

\footnotetext{
${ }^{4}$ The sufficient condition to ensure refinancing is $\boldsymbol{I}_{\boldsymbol{r + 1}}+\boldsymbol{D}_{\boldsymbol{\imath}} \leq \boldsymbol{V}_{\boldsymbol{t + 1}}$; this essentially implies that debt's marginal period tax disadvantage and/or future growh be of sufficient magnitude relative to debt's corporate tax advantage.
} 
The first-order condition can be written in terms of the fraction of expected earnings $C$ shielded from corporate tax by interest and, depreciation, which we call the optimal shielding ratio $z$ :

$$
\frac{I_{t+1}^{*}+B_{t+1}}{C_{t+1}}=z
$$

where

$$
z=\bar{F}^{-1}\left[\frac{\tau_{d}-\tau_{e}}{\left(1-\tau_{e}\right) \tau_{c}}\right]
$$

(The second-order condition ensures a maximum.) Corporate tax shielding due to depreciation is given by $b$, shielding due to interest is given by $z-b$. The optimal total shielding $z$ depends only on tax rates and the probability distribution of earnings, and not on inflation and real growth.

Assuming that the firm uses debt with fixed periodic interest payments, the optimal debt level is

$$
D_{i}^{*}=\frac{\left(1-\tau_{d}\right) I_{t+1}^{*}}{r}
$$

The optimal firm value is

$$
V_{l}^{*}=\frac{\left(1-\tau_{e}\right)\left[1-a-\tau_{c} \int_{z}^{\infty}(x-b) d F(x)\right] C_{t+1}}{r-\left(1-\tau_{g}\right) g}
$$

The optimal debt ratio is therefore

$$
\begin{aligned}
\left(\frac{D}{V}\right)_{t}^{*}= & \frac{r-\left(1-\tau_{g}\right) g}{r} \\
& \cdot \frac{\left(1-\tau_{d}\right)}{\left(1-\tau_{e}\right)\left[1-a-\tau_{c} \int_{z}^{\infty}(x-b) d F(x)\right]} \cdot\left(\frac{I}{C}\right)_{t+1}^{*}
\end{aligned}
$$

The additional distortions in the debt ratio as a measure of corporate tax shielding due to the capital gains tax and depreciation are captured by the first and second terms of Equation (4), respectively.

With a zero capital gains tax, the first term reduces to Equation (1); future growth accrues to equityholders. To clarify the effects of inflation and real growth in conjunction with a capital gains tax, rewrite the first term in terms of the tax-free real interest rate $R$, the real growth rate $G$, and the anticipated inflation rate $i$ :

$$
1-\left(1-\tau_{g}\right) \frac{G+\frac{1}{1+1}}{R+\frac{1}{1+1}}
$$


Although both higher inflation and higher real growth decrease this first term, the presence of the capital gains tax somewhat tempers this effect, increasing this term; part of future growth now accrues to the government.

The second term of Equation (4) captures the effect of using historic costs rather than current prices in depreciation. Both $a$ and $b$ depend on nominal growth. Since real growth is positively correlated with capital investment, a is increasing in real growth, although independent of inflation. Since allowed depreciation is based on historical spending, and the lag between historical and current spending increases with growth, $a-b$ is increasing in both real growth and inflation. ${ }^{5}$ The denominator of the second term can be written

$$
\left(1-\tau_{e}\right)\left(1-\left[1-\tau_{c} \bar{F}(z)\right] a-\tau_{c} \bar{F}(z)(a-b)-\tau_{c} \int_{z}^{\infty} x d F(x)\right)
$$

The effect of using historic depreciation is thus to increase the second term of Equation (4); both higher inflation and higher real growth make this effect stronger.

Intuitively, even if current cash flows accrue to debtholders, future growth accrues to equityholders, increasing firm value but not debt. both the capital gains tax and the use of historic depreciation lower the value of this growth. Since inflation increases the effective capital gains rate and lowers the real value of depreciation, it increases the tax burden on growth, lowering firm value. The wedge between debt and value due to growth is smaller: the debt ratio becomes a somewhat less distorted measure of interest shielding. The optimal debt ratio now depends on inflation, real growth, depreciation levels, and the real interest rate. However, the optimal total shielding ratio $z$ depends on none of these, while the optimal interest shielding ratio $z-b$ depends on only the depreciation level.

\subsection{Unlimited loss carryforwards and carrybacks}

In this section, a firm with unused shields generated by tax losses is allowed to carry them forward and backward to offset unshielded income of other years. To keep the model tractable, unlimited tax loss carrying (forward or backward) is allowed, and depreciation is considered only in the discussion at the section's end. Thus, the model of Section 3.1 is used, with $a=b=0$; however, tax shields may be fully carried forward or back (at their nominal value) indefinitely.

'For example, it is easy to check that $a-b$ increases with nomninal growth when capital investments ate depredated staight-line. A qualitatively similar result is obtained with any depredation schedule. 
How does this change the value maximization strategy of the firm? Consider the effect of allowing excess tax losses (shields) to be carried backward. If the firm finds itself at the end of period $t$ with positive taxable income, it takes on sufficient period $t+1$ interest to generate tax shields to fully (retroactively) shield the period $t$ income. (As before, it is assumed future cash flows are sufficient to issue desired debt.) Then, facing a clean slate, the firm takes on additional interest based on period $t+1$ earnings.

Now consider the effect of allowing excess tax losses to be carried forward. Suppose a firm finds itself at the end of period t with tax losses ("negative taxable income") available to be carried forward. The firm can then lower its period $t+1$ interest, replacing interest with loss carryforwards on a one-for-one basis.

Any corporate income left unshielded today will be shielded next year, although the firm may have tax exposure in the meantime. The benefits and costs of debt financing become the benefits and costs of using shielding today rather than waiting a year, reflecting the opportunity cost of shielding early. Without loss carryforwards and carrybacks, the (personal tax) cost of an extra dollar of interest is $\boldsymbol{\tau}_{\boldsymbol{d}}-\boldsymbol{\tau}_{\boldsymbol{e}}$, while the (corporate tax) benefit is $\left(\mathbf{1}-\boldsymbol{\tau}_{\boldsymbol{e}}\right) \boldsymbol{\tau}_{\boldsymbol{c}}$ times the probability of using the shield today. With carryforwards and carrybacks, the cost of an extra dollar of interest today (rather than next year) is the time value of paying $\boldsymbol{\tau}_{\boldsymbol{d}}-\boldsymbol{\tau}_{\boldsymbol{e}}$ today, while the benefit is the time value of getting $\left(1-\boldsymbol{\tau}_{\boldsymbol{e}}\right) \boldsymbol{\tau}_{\boldsymbol{c}}$ today times the probability of using the shield today.

Let $J_{t}=\sum_{s<t}\left(I_{s}-X_{3}\right) \mid$ the net shield carryforward (which may be positive or negative) from period $t$. The optimal capital structure policy becomes a dynamic programming problem where the firm value at any time depends on the current level of shield carryforward. As shown in the Appendix, the optimal level of current shielding satisfies

$$
\frac{I_{t+1}^{*}+J_{t}}{C_{t+1}}=z
$$

where $z$ is defined by Equation (3). Thus, the optimal capital structure may be interpreted as follows: at period $t+1$, all income realized through period $\mathrm{t}$ is fully shielded, while a fraction $z$ of expected period $t+1$ income is shielded.

This should not be interpreted as saying the firm pays no corporate tax (even in the long run). The ratio of interest to expected -earnings is

$$
\frac{I_{t+1}^{*}}{C_{t+1}}=\frac{z C_{t+1}-J_{t}}{C_{t+1}}=z-\frac{J_{t}}{C_{t+1}}
$$

which varies over time depending on the shield carryforward. The 
ratio of expected interest to expected earnings is

$$
\frac{z C_{t+1}+(1-z) C_{t}}{C_{t+1}}=z+\frac{1-z}{1+g}
$$

which measures total corporate tax shielding both instantaneously and cumulatively over firm life. Allowing carrying of tax losses pushes this tax shielding ratio nearer to unity, relative to the case without tax loss carrying (where the tax shielding ratio is $z$ ). For even moderate growth rates g, we may expect the tax shielding ratio to be near one: interest payments near expected earnings.

The effective, or average, corporate tax rate (expected corporate tax divided by expected earnings) is

$$
\tau_{c} \cdot \frac{g}{1+g} \cdot \int_{z}^{\infty}(x-z) d F(x)
$$

Allowing the firm to carry tax losses decreases the effective tax rate. Without loss carrying, the effective corporate tax rate is $\tau_{c} \int_{z}^{\infty}(x-$ $\boldsymbol{z}) \boldsymbol{d} \boldsymbol{F}(\boldsymbol{x})$.] At each point in time, the firm fully shields past income, but only imperfectly shields current income. As the firm grows, its current income increases; its average tax payments are thus positive. Note that both the effective corporate tax rate and the ratio of expected interest to expected earnings directly measure corporate tax shielding.

At each point in time, both the debt and the firm value depend on the net shield carryforward. The optimal debt level is

$$
D_{t}^{*}=\frac{\left(1-\tau_{d}\right) I_{t+1}^{*}}{r}=\frac{\left(1-\tau_{d}\right)\left(z C_{t+1}-J_{t}\right)}{r}
$$

The value of the firm is

$$
\begin{aligned}
V_{t}^{*}\left(J_{t}\right)= & \frac{\left(1-\tau_{e}\right)\left[1-\tau_{c} \int_{z}^{\infty} \frac{r x+1-\tau_{g}}{r+1-\tau_{R}} d F(x)\right] C_{t+1}}{r-\left(1-\tau_{g}\right) g} \\
& + \begin{cases}\frac{\tau_{f}-\tau_{g}}{r+1-\tau_{g}} J_{t}, & \text { if } J_{t} \geq 0 \\
\frac{\tau_{d}-\tau_{g}-\left(1-\tau_{g}\right) \tau_{s}}{r+1-\tau_{g}} J_{t}, & \text { if } J_{t}<0 .\end{cases}
\end{aligned}
$$

The firm value increases with the magnitude of $J_{t}$ : both a positive carryforward (having unused shields) and a negative carryforward (enhanced opportunity to utilize future shields) are valuable. The debt ratio depends on the net shield carryforward $J_{t}$, both in an absolute sense and relative to the ratio of interest to earnings. Thus, the net shield carryforward generates another distortion to the debt ratio as a measure of tax shielding. 
Example 3. Suppose firm earnings are distributed uniformly on $\left[0,2 C_{t}\right]$. Take tax rates of $\boldsymbol{\tau}_{c}=0.35, \boldsymbol{\tau}_{d}=0.396, \boldsymbol{\tau}_{\boldsymbol{g}}=0.28$, and $\boldsymbol{\tau}_{\boldsymbol{e}}=0.30$ (a strong overall advantage to debt financing). Take inflation of 3 percent, nominal growth of percent, and a tax-free (muni) interest rate of 6 percent.

If the firm cannot carry tax shields, ifs ratio of interest to expected earnings is 122 percent, and the effective corporate tax rate is 5.4 percent. Firm value is 23.9 times current expected earnings. Debt is 12.9 times current expected earnings, or 54 percent of firm value.

If the firm has unlimited shield carrying, its ratio of expected interest to expected earnings is 101 percent, while the effective corporate tax rate is only 0.2 percent: with unlimited tax loss carrying, the firm pays little corporate tax. Expected tax loss carryforward is 22 percent of current expected earnings. Expected firm value is 26.3 times expected current earnings. Expected debt is 10.7 times expected current earnings, or 41 percent of expected firm value.

Two extreme cases have been examined here: no tax loss carrying and unlimited tax loss carrying. Reality actually lies somewhere in between: the U.S. tax code allows for carryforwards and carrybacks, but they may only be carried for a limited time. Relative to the model of Section 3.2, the inclusion of depreciation and limited carrying of tax losses both reduce the benefit of interest tax shields. With depreciation, a substitute shield, excess shields may have to be carried over a longer time period, increasing the opportunity cost of shielding early. Limiting carrying opens up the possibility that interest shields may be lost forever. Roth depreciation and limited loss carrying are contained in the model of Section 3.1; thus, the inclusion of these effects would be expected to push the results in the direction of that model. Qualitatively, the debt ratio is still expected to provide a distorted view of actual tax shielding.

\subsection{Additional issues}

For a risky firm, some disadvantage to debt must be added to the Modigliani and Miller (1963) model to obtain an interior solution. Although this article has used personal taxes, similar results could be obtained in a model with bankruptcy or other financial distress costs (and uncertainty of earnings). At an interior optimum in such a tradeoff theory, a firm pays some corporate tax in order to decrease the probability of incurring bankruptcy or other financial distress. Qualitatively, the original point about the debt ratio still holds: even if the firm's interest payments are about the same size as its earnings, so that it mostly avoids corporate tax, the value of growth accrues to 
equityholders, so the debt ratio will not accurately measure tax shielding from debt.

Finally, we note that in a model with significant fixed costs of recapitalization, firms will take excursions away from their initial cap ital structures, as pointed out by Myers (1984), and modeled by Fischer, Heinkel, and Zechner (1989). In our simple example, the riskless growing firm (without adjustment costs) recapitalizes each period by issuing additional debt. With significant adjustment costs, the firm optimally issues additional debt less often. Realizing that its shielding needs will rise over time, the firm sets its initial level of debt higher than immediately necessary, expecting to grow into it. Thus, a firm that just issued new debt will be above its long-run "target" level. In contrast to Myers' random excursions away from optimal capital structure, the growing firm starts heavily shielded, becomes less shielded over time, then adjusts its debt level to become heavily shielded again. Thus, there will be some cross-sectional variation in interest coverage across firms sharing the same target interest coverage. Of course, differing growth rates across these firms will generate additional cross-sectional variation in their debt ratios.

\section{Implications for Research}

This section examines the implications for capital structure research. The difference between capital structure and the resulting tax savings is discussed in Section 4.1, as well as the implications of using different debt instruments. Empirical work in the field is then reexamined in Section 4.2, and preliminary evidence on the empirical difference between debt ratios and tax shielding is provided.

\subsection{Capital structure versus tax shielding}

Traditionally, the term capital structure has referred to a firm's split between debt and equity financing. Thus, a firm choosing an optimal capital structure is interpreted as choosing an optimal level of debt; in a dynamic setting, the firm chooses a set of optimal debt levels over time. However, -this focus on debt distracts from the most significant effect of capital structure policy, the corporate tax benefit. It is not the presence of debt that lowers taxable income and generates the familiar corporate tax savings. Rather, it is the presence of interest payments.

For example, suppose that a firm issues inflation-indexed bonds. Relative to a nonindexed bond with the same current interest payment, the indexed bond has a higher current value. A firm using indexed bonds affects its current debt ratio, but not its current interest payments (and thus its current corporate tax shielding). The term cap- 
ital structure has traditionally taken on two meanings, not necessarily synonymous: the debt level over time, and the interest payment level over time. We note that observing debt levels is not tantamount to observing interest levels. (Similarly, observing current earnings is not necessarily equivalent to observing firm value.)

Consider the simple case of a riskless firm with earnings growing at the inflation rate, $g=i$. To fully shield itself from taxes, interest payments should be $C$ next year, growing at rate $\mathrm{g}$ afterward. In Section 2, we outlined the most common way of generating this set of interest payments: start by issuing debt with fixed interest payments $\mathrm{C}$. (If any of this debt has finite maturity, roll over the debt as necessary; thus, the debt maturity is of no consequence for the firm here.) In the future, when additional interest payments are needed, issue additional debt. This strategy fully shields the firm, is therefore optimal, and yields a debt ratio less than 100 percent today and at all times in the future.

Other equally good strategies may be possible for the firm, if it has access to other debt financing instruments. For example, by issuing perpetual inflation-indexed bonds today, the firm could cover all future interest payments and need no future debt issues. This strategy also fully shields the firm, and is optimal, but yields a debt ratio of 100 percent today and at all times in the future.

Obviously, other strategies are possible, if the firm is not constrained to debt with fixed interest payments. By using different debt financing instruments, the fully shielded firm can achieve any arbitrary debt ratio between ${ }^{-}$and 100 percent. ${ }^{6}$ Which policy is optimal for the firm? Every strategy that fully shields the firm is equally good: the firm does not care about the debt ratio for its own sake. Thus, if by capital structure choice, we refer to both the choice of debt levels and forms of debt over time, then there are many optimal cap ital structures, with the optimal debt ratio undetermined. However, if by capital structure choice, we refer to the choice of interest payments over time, then the optimal capital structure is unique: each of the strategies above are equivalent ways of implementing that capital structure.

Although many strategies generate the optimal set of interest payments, there may be other reasons why firms typically use fixed payment debt. We note that the optimal capital structure sets interest relative to earnings on a period-by-period basis. By using a form of debt

${ }^{6}$ Lewis (1990) gives two additional masons (unrelated to growth) that a given set of interest payments may generate multiple optimal debt ratios: different maturities of debt may have different levels of \&fault risk, and current bond prices may be abducted by a nonflat term structure of interest rates. 
characterized by increasing interest payments, the firm commits itself earlier to making a certain level of interest payments. If the firm expects to receive new information about real growth in future earnings, there may be reasons to wait for that information before committing to an interest payment level, although such a model is beyond the scope of this article.

\subsection{Implications for empirical work}

The principal empirical implication of the analysis is that the debt ratio does not appropriately measure the actual tax shielding of debt. The debt ratio is therefore an inappropriate instrument for empirically testing the trade-off theory of capital structure; after all, not only is the corporate tax advantage of debt the principal benefit, but the personal tax disadvantage is a principal cost associated with debt financing. Both the corporate tax advantage and the personal tax disadvantage are distorted by the debt ratio.

Empirical studies that test the trade-offs associated with capital structure by examining corporate debt (or debt-equity) ratios are misguided. A large amount of empirical work has sought to identify the determinants of capital structure and concomitantly the validity of the trade-off theory. Early work on this subject achieved notably poor results in developing a consensus on the determinants of capital structure. A representative example of early capital structure studies is Bradley, Jarrell, and Kim (1984), a cross-sectional study using aggregate data from 1962 to 1981 . They find that asset volatility, nondebt tax shields, and advertising/R\&D expenses are significant determinants of debt ratios. These factors, in addition to many others, have been used in a myriad of additional empirical studies, but these studies failed to come to a consensus on identifying the statistically significant determinants of capital structure. Myers (1984) notes, "I know of no study clearly demonstrating that a firm's tax status has predictable, material effects on its debt policy."

Kim and Sorensen (1986) and Titman and Wessels (1988) measure the impact of growth opportunities on leverage ratios to test Myers' (1977) theory of the agency cost of debt finance. Both studies find that growth opportunities are negatively related to leverage, although only in Kim and Sorensen is the relationship statistically significant. However, a negative relationship found using tests specified in terms of debt ratios may be the manifestation of agency costs of growth, or may simply be due to the distortion induced by growth in firms' cash flows.

Unfortunately, these studies do not assess the effect of growth on direct measures of tax shielding; the vast majority of empirical tests of capital structure use debt ratios to measure tax shielding. If an alternative measure is included, it is usually (book value of) debt 
divided by either total assets or book value of debt and equity, also deficient measures of debt's tax benefits. The lack of consensus as to the empirically significant determinants of capital structure is therefore unsurprising. Since the trade-off theory posits that interest is used until its marginal benefit equals its marginal costs, empirical testing should use a dependent variable reflecting the marginal benefit of interest tax shields as closely as possible.

Recent empirical tests of the trade-off theory are more positive. Givoly, Hayn, Ofer, and Sarig (1992), using the period surrounding the Tax Reform Act of 1986 to determine whether tax-based theories are descriptive of firms' capital structure decisions, find evidence supporting the tradeoff theory. MacKie-Mason (1990) finds results consistent with firms making financing choices reflecting their marginal tax benefit. Trezevant (1992) finds that investment tax shields and interest tax shields behaved as substitutes in response to the Economic Recovery Tax Act of 1981, further evidence supporting the tradeoff theory. These three studies avoid some of the measurement problems associated with earlier trade-off theory studies by observing debt changes in response to an event that affects firms' tax exposure, and provide evidence supporting the trade-off theory.

Ideally, future testing of the trade-off theory should use proxies for tax shielding that are unaffected by growth (such as interest to expected earnings). Much of the capital structure puzzle may be attributable to the use of proxies for tax shielding that are strongly affected by growth. Properly considering growth highlights the importance of appropriately measuring the magnitude of tax shields.

There is evidence that the apparent tax shielding is sensitive to the measure used. For firms in the COMPUSTAT database having complete data history over the period 1974 to 1993 (excluding foreign and financials, giving 1625 firms), the median debt ratio is 33.5 percent, with first and third quartile values of 16.7 percent and 49.6 percent. Debt ratio is calculated here as book value of total debt over book value of total debt and preferred equity plus market value of common equity: DT/(DT+PSTK+MKVAL), with each component summed across years. (Year-by-year results are similar.)

The actual fraction of income shielded by these firms is substantially different. The shielding ratio is calculated as the fraction of the statutory federal tax rate times income not actually paid as tax: $\left(\tau_{c} \cdot\right.$ OIBDP - TXFED) $/ \tau_{c} \cdot$ OIBDP, , with each component summed across years. For the 1625 firms during this period, the median shielding ratio is 74.8 percent, with first and third quartile values of 55.1 percent and 89.7 percent.

The difference in debt ratios and shielding ratios may go beyond simple magnitudes. For example, firms with low debt ratios need not 
have low shielding ratios. In order to measure the coincidence of debt ratios and shielding ratios, we perform a rank correlation. Over the 1625 firms in the sample, the rank correlation of the debt ratio and shielding ratio is 0.457 .

A third measure of tax shielding yielding different results is the interest to payout ratio, where payout is defined as interest plus dividends plus net share repurchases. Although it does not measure tax shielding directly, further evidence of the distortion of the debt ratio is gained by examining the ratio of interest to payout. Note that payout is not dependent on the firm's dividend policy. If new stock is issued to pay for a dividend increase, the decrease in net share repurchases is exactly offset by the dividend increase, leaving payout unchanged. If dividends are replaced with share repurchases, the decrease in dividends is offset by the increase in net share repurchases, again leaving payout unchanged.

For the simple case of a riskless growing firm (from Section 2), payout $P$ equals

$$
P_{t+1}=\left(1-\tau_{c}\right) C_{t+1}+\tau_{c} I_{t+1}+g D_{t} .
$$

The third term represents funds raised from net debt issues. For positive growth, the optimal capital structure is $I^{*}=C$, an interest to earnings ratio of 100 percent. It is straightforward to show that the interest to payout ratio then equals

$$
\left(\frac{I}{P}\right)^{*}=\frac{r_{f}}{r_{f}+g} .
$$

The debt ratio is given by Equation (1). Interest to payout is therefore greater than the debt ratio, although still less than the actual tax shielding of interest to earnings.

Example 4. Consider the effect of inflation on the fully shielded riskless firm with zero real growth. The interest to earnings ratio is 100 percent. With 1974 to 1993 estimates of $r_{f}=9.2$ percent and inflation of 5.9 percent, the debt ratio is 36 percent, and the interest to payout ratio is 61 percent.

The interest to payout ratio is calculated as interest over interest plus dividends plus net share repurchases: : XINT/(XINT + DIV $+\Delta$ CSHO PR), with each component summed across years. For the 1625 firms during this period, the median interest to payout ratio is 60.2 percent, with first and third quartile values of 38.1 percent and 89.1 percent. (Year-by-year results are similar.) The apparent tax shielding is thus 
sensitive to the measure used; the interest to payout ratio seems to be distorted less than the debt ratio as a measure of shielding.

We believe the efforts of the profession should no longer be spent trying to explain the level and variation of debt ratios, in an effort to find whether tax shielding is important. The preliminary evidence of the shielding ratios indicates that firms may pay less corporate tax than indicated by debt ratios. A properly executed trade-off theory of capital structure should try to explain the magnitude of tax payments in terms of bankruptcy costs, agency costs, asymmetric information, product/input market interactions, corporate control considerations, or other reasons.

\section{Conclusion}

This article shows that nominal firm growth, due to inflation or teal growth, distorts the debt ratio as a measure of tax shielding. Firms typically issue debt characterized by fixed interest payments, even when they expect positive growth in earnings. To totally shield itself from corporate tax, a firm should not set debt equal to firm value. Instead, it should set its current interest payments equal to current earnings. In the face of positive nominal growth, this is not at all the same thing. Even if all current earnings accrue to debtholders, growth (both inflationary and real) accrues to equityholders. Thus, for example, a riskless firm fully shielded from tax may have a debt ratio significantly below 100 percent.

There are a number of additional factors which may distort the debt ratio as a measure of tax shielding. Inflation affects the effective real tax rate on capital gains, making growth less valuable on an after-tax basis. Because depreciation is based on historic cost, the relative size of depreciation-based shields is affected by both inflationary and real growth. These factors both distort the debt ratio. When the firm can carry tax losses, distortion of the debt ratio depends on the net losses carried forward, which may vary over time. Thus, there are a number of factors which can generate significant cross-sectional variation in debt ratios without corresponding variation in tax shielding. [For example, debt ratios and growth rates may be inversely related across firms of equal tax shielding, even without the agency costs of Myers (1977).]

Since the trade-off theory of capital structure is primarily driven by the corporate tax benefits of debt financing, it is important to recognize that the debt ratio provides a distorted measure of corporate tax shielding when testing the theory. To appropriately test the tradeoff theory, the magnitude of corporate tax payments, and how those payments are related to various costs of debt, should be more directly examined. 


\section{Appendix}

We analyze the dynamic programming problem faced by the firm with unlimited carryforwards and carrybacks. The period $t$ optimization problem can be written as

$$
\begin{aligned}
(1+r) V_{t}\left(J_{t}\right)= & \max _{I_{t+1}} E_{t}\left(V_{t+1}\left(\tilde{J}_{t+1}\right)-\tau_{g}\left[V_{t+1}\left(\tilde{J}_{t+1}\right)-V_{t}\left(J_{t}\right)\right]\right) \\
& +\left(1-\tau_{d}\right) I_{t+1}+\left(1-\tau_{e}\right) E_{t} \\
& \times\left(\tilde{X}_{t+1}-I_{t+1}-\tau_{c} \cdot\left\{\begin{array}{c}
\max \left(\tilde{X}_{t+1}-I_{t+1}-J_{t}, 0\right) \\
\text { if } J_{t} \geq 0, \\
\max \left(\tilde{X}_{t+1}-I_{t+1}, J_{t}\right) \\
\text { if } J_{t}<0,
\end{array}\right),\right.
\end{aligned}
$$

subject to $J_{t+1}=J_{t}+I_{t+1}-X_{t+1}$. We posit the solution form

$$
V_{t}\left(J_{t}\right)=V_{t}+ \begin{cases}\alpha J_{t} & \text { if } J_{t} \geq 0, \\ \beta J_{t} & \text { if } J_{t}<0,\end{cases}
$$

where $\boldsymbol{V}_{\boldsymbol{t}}$ is independent of $\boldsymbol{J}_{\boldsymbol{t}}$. Defining $\boldsymbol{z}$ by $\boldsymbol{I}_{\boldsymbol{t}+1}^{*}+\boldsymbol{J}_{\boldsymbol{t}}=\boldsymbol{z} \boldsymbol{C}_{\boldsymbol{t}+1}$, substituting, and collecting terms, the period $\boldsymbol{t}$ optimization problem can be written as

$$
\begin{aligned}
{[1+r} & \left.-\tau_{g}-\left(1-\tau_{g}\right)(1+g)\right] V_{t} \\
\quad= & \max _{z}\left(1-\tau_{g}\right)\left[\alpha(z-1)+(\alpha-\beta) \int_{z}^{\infty}(x-z) d F(x)\right] C_{t+1} \\
& \quad-\left(\tau_{d}-\tau_{e}\right) z C_{t+1}+\left(1-\tau_{e}\right)\left[1-\tau_{c} \int_{z}^{\infty}(x-z) d F(x)\right] C_{t+1},
\end{aligned}
$$

with

$$
\begin{aligned}
& \left(1+r-\tau_{g}\right) \alpha=\left(\tau_{d}-\tau_{e}\right) \\
& \left(1+r-\tau_{g}\right) \beta=\left(\tau_{d}-\tau_{e}\right)-\left(1-\tau_{e}\right) \tau_{c} .
\end{aligned}
$$

This determines a and $\boldsymbol{\beta}$. The first-order condition is

$$
\left(1-\tau_{g}\right)[\alpha-(\alpha-\beta) \bar{F}(z)]-\left(\tau_{d}-\tau_{e}\right)+\left(1-\tau_{e}\right) \tau_{c} \bar{F}(z)=0 .
$$

Substituting for a and $\boldsymbol{\beta}$ and simplifying, this gives

$$
\bar{F}(z)=\frac{\tau_{d}-\tau_{e}}{\left(1-\tau_{e}\right) \tau_{c}}
$$


independent of $t$. The second-order condition is negative when the density $f(z)$ is positive. Using the first-order condition and simplifying, we can write

$$
V_{t}=\left[1-\tau_{c} \int_{z}^{\infty} \frac{r x+1-\tau_{g}}{r+1-\tau_{g}} d F(x)\right] \frac{\left(1-\tau_{e}\right) C_{t+1}}{r-\left(1-\tau_{g}\right) g}
$$

This solves the optimization problem.

\section{References}

Barnea, A., R. A. Haugen, and E. Talmor, 1987, "Debt and Taxes: A Multiperiod Investigation, Journal of Banking and Finance, 11,79-97.

Bradley, M., G. A. Jarrell, and E. H. Kim, 1984, "On the Existence of an Optimal Capital Structure: Theory and Evidence," Journal of Finance, 39, 857-878.

DeAngelo, H., and R W. Masulis, 1980, "Optimal Capital Structure Under Corporate and Personal Taxation," Journal of Financial Economics, 8, 3-29.

Farrar, D. E., and L. L Selwyn, 1967, Taxes, Corporate Financial Policy, and Returns to Investors," National Tax Journal, 20, 444-454.

Feldstein, M., 1980, "Inflation and the Stock Markets, American Economic Review, 70, 839-847.

Fischer, E. O., R. Heinkel, and J. Zechner, 1989, "Dynamic capital Structure Choice: Theory and Tests," Journal of Finance, 44, 19-40.

Givoly, D., C. Hayn, A. R. Ofer, and O. Sarig, 1992. "Taxes and Capital Structure: Evidence from Firms' Response in the Tax Reform Act of 1986," Review of Financial Studies, 5, 331-355.

Harris, M., and A. Raviv, 1991, "The Theory of Capital Structure," Journal of Financial, 46, 297-355. Hong, H., 1977, "Inflation and the Market Value of the Firm: Theory and Tests," Journal of Finance 32, 1031-1048

Ibbotson Associates, 1994, Stock, Bonds, Bills, and Inflation 1994 Yearbook, Ibbotson Associates, Chicago.

Kim, W. S., and E. H. Sorensen, 1986, "Evidence on the Impact of the Agency Costs of Debt in Corporate Debt Policy," Journal of Financial and Quantitative Analysis, 21, 131-144.

Lewis, C. M., 1990, “A Multiperiod Theory of Corporate Financial Policy under Taxation” Journal of Financial and Quantitative Analysis, 25, 25-43.

Mackiie-Mason, J.K., 1990, "Do Taxes Affect Corporate Financing Decisions?" Journal of Finance, $45, \quad 1471-1493$

Masulis, R. M.. 1988, The Debt Choice, Ballinger, Cambridge, Mass.

Mayer, C., 1986, "Corporation Tax, Finance, and the Cast of Capital," Review of Economic Studies, 53, 93-112.

Miller, M. H., 1977, “Debt and Taxes,” Journal of Finance, 32, 261-275.

Miller, M. H., 1988. The Modigliani-Miller Propositions After Thirty Years," Journal of Economic Perspectives, 2, 99-120. 
Modigliani, F., 1982, "Debt, Dividend Policy, Taxes, Inflation and Market Valuation," Journal of Finance, 37, 255-273.

Modigliani, F., and M. H. Miller, 1963, 'Corporate Income Taxes and the Cost of Capital: A Correction," American Economic Review, 53, 443-443.

Myers, S. C., 1977. "Determinants of Corporate Borrowing," Journal of Financial Economics, 5, $147-175$.

Myers, S. C., 1984, “The Capital Structure Puzzle,” Journal of Finance, 39, 575-592.

Nelson, C. R, 1976, “Inflation and Capital Budgeting,” 'Journal of Finance, 31, 923-931.

Schall, L. D., 1954, Taxes, Inflation, and Corporate Financial Policy,” Journal of Finance, 39,

Titman, S., and R Wessels, 1988, The Determinants of Capital Structure Choice," Journal of Finance, 43, 1-19.

Trezevant, R, 1992, 'Debt Financing and Tax Status: Tests of the Substitution Effect and the Tax Exhaustion Hypothesis Using Firms' Responses to the Economic Recovery Tax Act of 1981," Journal of Finance, 47, 1557-1568 